\title{
An amazing meeting arrangement on messenger RNA genes
}

\author{
THORU PEDERSON \\ Department of Biochemistry and Molecular Pharmacology, University of Massachusetts Medical School, Worcester, Massachusetts 01605, USA
}

Convened at Cold Spring Harbor Laboratory on October 22-25, 2017, "Forty Years of mRNA Splicing: From Discovery to Therapeutics" was one in a series of meetings held by the Laboratory's Genentech Center for the History of Molecular Biology and Biotechnology (http://library.cshl. edu/Meetings/History-of-Science/), organized by Mila Pollock, Executive Director of Library and Archives, and on this occasion co-organized by Phil Sharp (MIT) and Joan Steitz (Yale) (Fig. 1). In coming up with a title for this report, I could not resist punning that of one of the two seminal papers (Berget et al. 1977; Chow et al. 1977).

The format of the meeting hybridized (no pun intended) reminiscent vignettes by early pioneers coupled with their more recent work in some cases, interspersed with other talks by key players who entered the field later. Space considerations limit this account to only a general sense of what took place and I have admittedly been selective and, due to the historical focus of the meeting, I have somewhat disproportionately covered various senior figures, notwithstanding the embracing egalitarian philosophy of the RNA community. This was certainly one of the scientifically richest and most epistemologically delightful meetings I have ever attended.

Prior to and after the discovery of introns, no one contributed more to the biosynthesis of messenger RNA in eukaryotes than Jim Darnell (Rockefeller), and his opening talk reminded both the senior and younger members of the audience of our great debt to him. The subsequent talks were by Phil Sharp (an admitted personal story and well hewn) and Rich Roberts (New England BioLabs) followed by Rich Gelinas (Institute for Systems Biology) and Louise Chow (University of Alabama) to add details of their discovery at CSHL with Roberts and Tom Broker. Listening to these talks, a historical point occurred to me, related to Norman Davidson at Caltech. Had Phil Sharp not gone there for a post-doc and learned R-loop mapping, and had CSHL not continued to run an EM lab after the departure of its former leader, Hajo Delius, resulting in Louise Chow's appointment, who knows where and how mRNA splicing might have been discovered.

Corresponding author: thoru.pederson@umassmed.edu

Article is online at http://www.rnajournal.org/cgi/doi/10.1261/rna. 065052.117 .
Also in this session, Joan Steitz recalled the monumental discovery of autoantibodies for the snRNPs by Michael Lerner in her lab and also described how she and Tom Steitz got onto the two metal ion-mechanism of mRNA splicing during their productive sabbatical at Colorado. During a subsequent panel session, Tom Cech (Boulder) reminded the audience that Tetrahymena ribosomal RNA splicing, which his lab worked out (Zaug et al. 1983), foreshadowed the later-defined mRNA splicing reaction. Both are RNA-catalyzed: the former intramolecular, the latter intermolecular, phosphoryl group transfers (a.k.a. transesterification reactions) proceeding via a nucleophile SN2 mechanism. This enabling terminology was introduced by his group at the time and soon became standard nomenclature as the mRNA splicing details came into view.

Another key talk in this opening session was by Michael Rosbash (Brandeis), who made major contributions to the mRNA splicing field before then moving into circadian biology for which he will share the 2017 Nobel Prize in Physiology or Medicine. Just as he was about to speak, CSHL President Bruce Stillman appeared with a tray of glasses and a bottle of champagne and called forward Tom Cech, Wally Gilbert, Rich Roberts, Phil Sharp, and Joan Steitz for a toast to Michael. This was one of two standing ovations at the meeting - the second to be described shortly.

Later in the meeting, there were more historical reflections, of which the most engaging for me was that by Wally Gilbert (Harvard) as he went through the cerebral foreplay that engendered his prescient paper on introns (Fig. 2; Gilbert 1978). I was especially pleased that he reminded us all that the terms "exon" and "intron" he coined were not based on sequences remaining in the nucleus or leaving, as many textbooks say and as I have often had to correct students, but were cast in terms of the already elegant term "cistron," intron meaning "intra-cistron" and exon meaning a translationally expressed portion.

Alternative splicing, only remotely envisioned at the time mRNA introns were discovered, was the focus of several talks.

(C) 2018 Pederson This article is distributed exclusively by the RNA Society for the first 12 months after the full-issue publication date (see http:// rnajournal.cshlp.org/site/misc/terms.xhtml). After 12 months, it is available under a Creative Commons License (Attribution-NonCommercial 4.0 International), as described at http://creativecommons.org/licenses/by-nc/ $4.0 /$. 


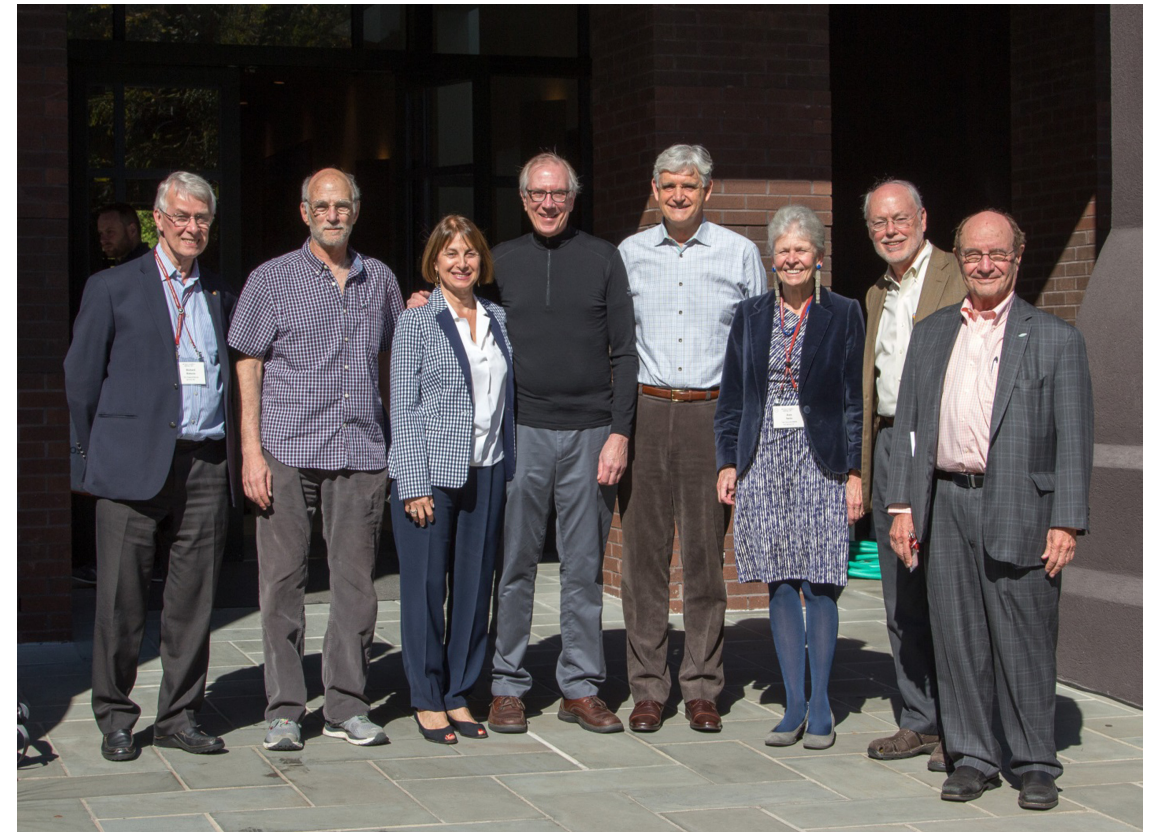

FIGURE 1. Meeting organizers and other principals. (Left to right) Rich Roberts, Michael Rosbash, Mila Pollock, Tom Cech, Bruce Stillman, Joan Steitz, Phil Sharp, and Wally Gilbert. (Courtesy of the Cold Spring Harbor Laboratory Archives.)

Larry Lipursky (UCLA) described the astonishing arsenal of alternatively spliced mRNAs encoding the cell surface diversity required to elaborate the Drosophila nervous system. Tom Maniatis (Columbia), himself a mRNA splicing pioneer, then presented results from his "new career"-studies of the mammalian protocadherin gene family, which fulfills the same function as in the Drosophila system. However, in mammals, cell surface diversity is generated by an entirely different mechanism: stochastic promoter choice and mRNA splicing rather than massive alternative splicing. These talks thus provided a striking example of convergent evolution. Robert Darnell (Rockefeller) described how the neuronal RNA-binding protein NOVA2 regulates alternative splicing of the same transcripts in diverse neuronal cell types in the mouse brain.

At the beginning of the splicing field, some (many?) thought that there might be a machine like the ribosome, through which the pre-mRNA was threaded and handled. Even though the ribosome goes through some amazing contortions during the sequential steps of mRNA translation, it does not essentially rebuild itself at each step as does the spliceosome. Several talks emphasized the complex spliceosome cycle that has been revealed over the past years and then came a crowning moment of the meeting. The increasingly high-resolution X-ray crystallography and breathtaking cryo-EM advances by Reinhard Lührmann (MaxPlanck, Göttingen), Kiyoshi Nagai (Cambridge, UK), and Yigong Shi (Beijing) astounded the audience, creating a buzz of talk all through the rest of the meeting as well as a subsequent standing ovation summoned by the organizers.

As promised in the meeting's title, there was excellent coverage of diseaserelated work. David Spector (Cold Spring Harbor) took the audience from his early, seminal work on nucleoplasmic speckles to a cancer relevant noncoding nuclear RNA with clinical investigations imminent. Jim Manley (Columbia) described how the sequestration of the hnRNP $\mathrm{H}$ protein and the resultant decrease in its intranuclear concentration markedly influence the patterns of alternative mRNA splicing in one form of amyotrophic lateral sclerosis. Siddhartha Mukherjee (Columbia) presented the results of RNA-seq studies on missplicing mutations of the MAP3K7 gene in myeloid cells of patients with myelodysplastic syndromes. All of these reported efforts are promising, and a compelling basis for optimism was the talk by Adrian Krainer (Cold Spring Harbor) on exon 7 skipping in the SMN2 gene as the basis for spinal muscular atrophy, following from his

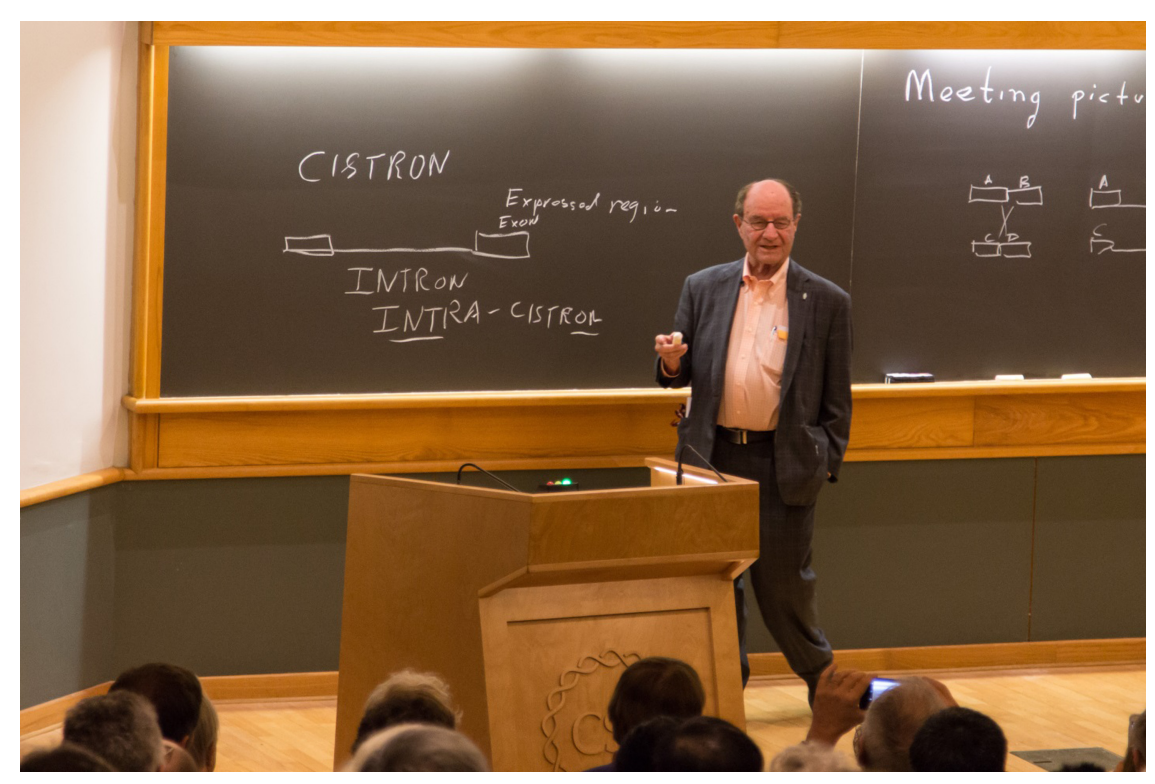

FIGURE 2. Wally Gilbert, talking about his prescient 1978 ideas (Gilbert 1978). (Courtesy of the Cold Spring Harbor Laboratory Archives.) 


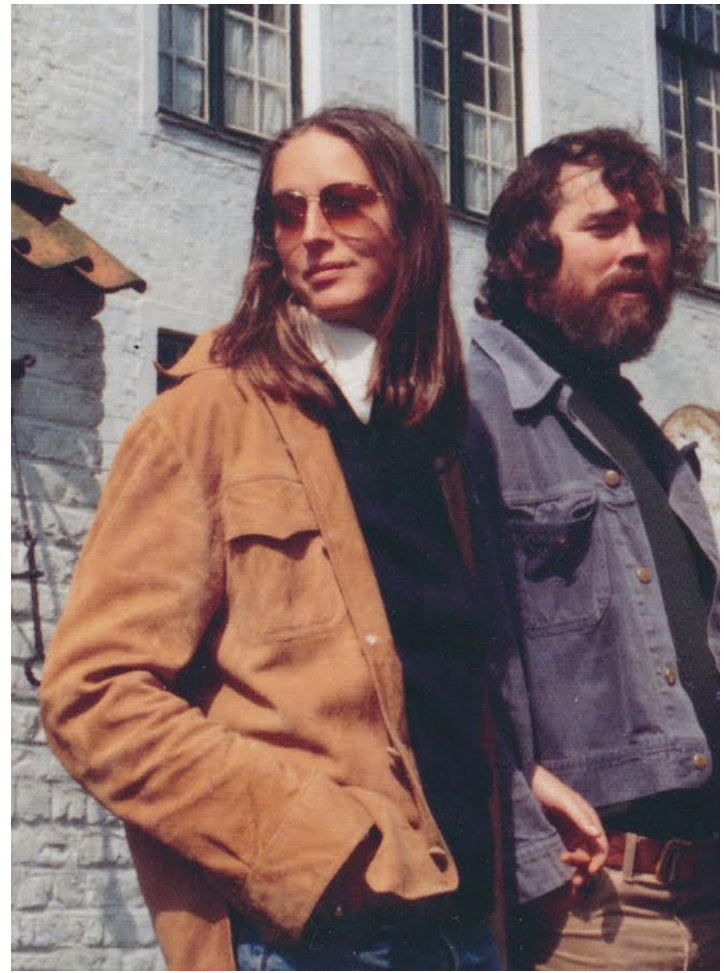

FIGURE 3. Christine Guthrie and John Abelson circa 1974. (Taken by James Dahlberg in Bruges, Belgium and used with permission of the subjects.)

pioneering work on alternative mRNA splicing to the recent advent of the antisense oligo drug Spinraza. The clinical results being reported are nothing less than amazing and, as one who started an antisense therapeutic company that failed (Pederson 2012), I felt—as I think all the audience did—I was a witness to history.

There were some key people who did not or could not attend and were so missed, including Susan Berget. At the break the first night, Joan Steitz put up a slide (Fig. 3) and there was an emotional reaction by all of the senior members of the audience who missed these two cherished colleagues and admired leaders who wrote: "Dear Everyone: Sorry we can't be there to recall those early years of splicing. Anyway, probably better to remember us as we were in 1974. Love to all, John and Chris." Also unable to attend was Jim Watson, his absence felt by so many. He launched the adenovirus program at CSHL as a foray into cancer, recruiting the likes of Walter Keller, Carel Mulder, Ulf Pettersson, Rich Roberts, Joe Sambrook, Phil Sharp and others that resulted in a revolution in the molecular biology of tumor viruses. The program did not go very far as cancer, but it went very far indeed as foundational RNA science.

All through the meeting, I kept my eyes on the students and post-docs as most of them saw iconic figures and textbook names in person for the first time. I also acutely and pleasurably realized how these younger attendees were learning how women had been so prominent in this field early on and have been subsequently.

Meanwhile, attendees of my generation likely felt two contrasting emotions throughout this extraordinary meetingdelight that we were in the field at the time, and a certain bittersweet sense that our lives in science may never be as thrilling ever again. It seems hard to imagine that anything will ever dazzle us so much as did the discovery of introns. But then, just think of how a second form of bacterial immunity (beyond protein enzyme-based host restriction) has recently captivated us, for example. So, we should continue to search for all new things under the sun, and compel the next generation to have these same dreams. It is what we do and, thankfully, for science and society, we cannot help ourselves.

\section{REFERENCES}

Berget SM, Moore C, Sharp PA. 1977. Spliced segments at the $5^{\prime}$ terminus of adenovirus 2 late mRNA. Proc Natl Acad Sci 74: 3171-3175.

Chow LT, Gelinas RE, Broker TR, Roberts RJ. 1977. An amazing sequence arrangement at the $5^{\prime}$ ends of adenovirus 2 messenger RNA. Cell 12: 1-8.

Gilbert W. 1978. Why genes in pieces? Nature 271: 501.

Pederson T. 2012. Sense and antisense in biotech: the first antisense DNA company. FASEB J 26: 3594-3601.

Zaug AJ, Grabowski PJ, Cech TR. 1983. Autocatalytic cyclization of an excised intervening sequence RNA is a cleavage-ligation reaction. Cell 301: 578-583. 

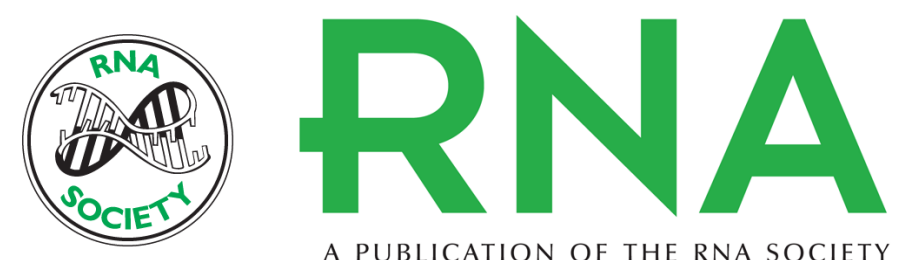

A PUBLICATION OF THE RNA SOCIETY

\section{An amazing meeting arrangement on messenger RNA genes}

\section{Thoru Pederson}

RNA 2018 24: 259-261 originally published online December 5, 2017

Access the most recent version at doi:10.1261/rna.065052.117

\section{References}

Creative Commons License

Email Alerting Service
This article cites 5 articles, 1 of which can be accessed free at: http://rnajournal.cshlp.org/content/24/3/259.full.html\#ref-list-1

This article is distributed exclusively by the RNA Society for the first 12 months after the full-issue publication date (see http://rnajournal.cshlp.org/site/misc/terms.xhtml). After 12 months, it is available under a Creative Commons License (Attribution-NonCommercial 4.0 International), as described at http://creativecommons.org/licenses/by-nc/4.0/.

Receive free email alerts when new articles cite this article - sign up in the box at the top right corner of the article or click here. 